\title{
Direct stimulatory effect of ghrelin on pituitary release of LH through a nitric oxide-dependent mechanism that is modulated by estrogen
}

\author{
Rafael Fernández-Fernández, Manuel Tena-Sempere, Juan Roa, Juan Manuel Castellano, \\ Víctor M Navarro, Enrique Aguilar and Leonor Pinilla
}

Physiology Section, Faculty of Medicine, University of Córdoba, 14004 Cordoba, Spain

Correspondence should be addressed to L Pinilla; Email: fi1agbee@uco.es

\begin{abstract}
Ghrelin, a gut peptide with key actions on food intake and $\mathrm{GH}$ secretion, has been recently recognized as potential regulator of reproductive function. Thus, in adult female rats, ghrelin has been proven to modulate GnRH/LH secretion, with predominant inhibitory effects in vivo. We analyze herein potential direct pituitary effects of ghrelin on basal and GnRH-stimulated gonadotropin secretion in prepubertal female rats, and its interplay with ovarian inputs, nitric oxide (NO), and hypothalamic differentiation. In the experimental setting, pituitaries from intact and ovariectomized prepubertal female rats were challenged with ghrelin in vitro and LH secretion was monitored. Our results demonstrate that 1) ghrelin consistently stimulated in vitro pituitary LH secretion under different experimental conditions; 2) the sensitivity to ghrelin, expressed either as the minimal effective dose or the amplitude of the LH response, was modulated by ovarian inputs; 3) the blockade of estrogen action significantly augmented the stimulatory effect of ghrelin; 4) the stimulatory effect of ghrelin on LH secretion required proper NO synthesis; and 5) the ability of ghrelin to elicit $\mathrm{LH}$ secretion in vitro was preserved after alteration (masculinization) of brain sexual differentiation. Overall, our present data reinforce the concept that ghrelin participates in the control of LH secretion, with potential stimulatory actions at the pituitary level that require the presence of $\mathrm{NO}$ and are modulated by ovarian signals. Reproduction (2007) 133 1223-1232
\end{abstract}

\section{Introduction}

Although it has been long known that conditions of negative energy balance are frequently linked to lack of puberty onset and reproductive failure, only recently the mechanisms involved in the coupling of reproductive function and body energy stores have been partially elucidated (for a review, see Fernández-Fernández et al. 2006). In this context, recent evidence has demostrated that central and peripheral endocrine signals governing energy homeostasis, such as the adipocyte-derived hormone leptin, the gastrointestinal-secreted molecule polypeptide $\mathrm{YY}_{3-36}$, the neuropeptide $\mathrm{Y}$ (NPY), and orexins, are also involved in the control of reproductive function by acting at different levels of hypothalamicpituitary-gonadal axis (Kalra \& Crowley 1992, Pu et al. 1998, Casanueva \& Diéguez 1999, Tamura et al. 1999, Ahima et al. 2000, Tena-Sempere \& Barreiro 2002, Fernández-Fernández et al. 2005a). Proper reproductive function requires the precise regulation of gonadotropin secretion, which is achieved via complex interactions between gonadotrophin-releasing hormone (GnRH), other hypothalamic peptides (Evans 1999, Moore et al. 2003), local pituitary signals (such as activins, inhibins, and follistatin; Meunier et al. 1988, Kogawa et al. 1991), and gonadal-derived steroids and peptides. In addition, it is known that sexual differentiation of the neuronal circuitry controlling gonadotropin secretion in adult age occurs in rodents during the neonatal period and is steroid dependent (Barraclough 1961, Gorski 1963, 1990). This differentiation can be impaired by exogenous administration of sexual steroids (Barraclough 1961, Gorski 1963, 1990, Bellido et al. 1985, Pinilla et al. 1992).

Ghrelin, a 28-amino acid peptide with an essential n-octanoylation at serine 3 , is mainly expressed in stomach (Kojima et al. 1999, 2001) and stimulates food intake and growth hormone $(\mathrm{GH})$ secretion in humans and rats (Kojima et al. 1999, 2001, Seoane et al. 2000, Wren et al. 2000, Ahnfelt-Ronne et al. 2001, Arvat et al. 2001a, 2001b, Ghigo et al. 2001, Hataya et al. 2001, Tayaka et al. 2001, Pinilla et al. 2003). These biological 
effects are conducted through its interaction with the $\mathrm{GH}$ secretagogue receptor (GHS-R), a member of the large family of G-protein coupled, seven transmembrane domain receptors. Two GHS-R subtypes, generated by alternative splicing of a single gene, have been described so far: the full-length type 1 a receptor and the truncated GHS-R type $1 b$; the GHS-R1a being the functionally active, signal transducing form of the receptor (Howard et al. 1996, McKee et al. 1997). In addition to the important role of ghrelin in the control of $\mathrm{GH}$ secretion and energy homeostasis, ghrelin carries out a plethora of endocrine and non-endocrine biological actions (Korbonits et al. 2004, van der Lely et al. 2004).

In the context of the proven role of ghrelin as a potent orexigenic hormone involved in the long-term control of body weight (Wren et al. 2000, Korbonits et al. 2004), recent data have suggested role of ghrelin in the regulation of reproduction, with a predominantly inhibitory effect upon reproductive function in primate and rodent species. Thus, expression of ghrelin has been demonstrated in human and rodent placenta, and ghrelin has been reported to inhibit early embryo development in vitro (Gualillo et al. 2001, Kawamura et al. 2003), and pregnancy outcome in vivo (Fernández-Fernández et al. 2005b). In addition, acute and chronic administration of ghrelin was shown to suppress luteinizing hormone (LH) secretion in vivo in prepubertal and adult male and female rats and monkeys (Furuta et al. 2001, Fernández-Fernández et al. 2004, 2005b, 2005c, Vulliémoz et al. 2004, Martini et al. 2006) and to decrease in vitro GnRH secretion (Fernández-Fernández et al. 2005c) and LH responsiveness to GnRH (Fernández-Fernández et al. 2004, 2005c). Moreover, ghrelin was able to inhibit testosterone secretion in vivo and in vitro (Tena-Sempere et al. 2002, Fernández-Fernández et al. 2005b) and partially prevented the normal timing of balanopreputial separation, an external index of puberty onset, in rats (Fernández-Fernández et al. 2005b, Martini et al. 2006). Finally, expression of ghrelin and its cognate receptor has been demonstrated in rat and human gonads (Barreiro et al. 2002, 2003, Tena-Sempere et al. 2002, Gaytán et al. 2003, 2004) and GHS-R1a mRNA has been detected in pituitaries from adult female rats in all phases of estrous cycle (Fernández-Fernández et al. 2005c). Finally, in conditions of negative energy balance, such as fasting or anorexia nervosa, high plasma levels of ghrelin are accompanied by decreased LH secretion (Camina et al. 2003, Misra et al. 2005), which is compatible with its potential inhibitory effect upon reproductive function.

Despite its suggested inhibitory role in the central control of the gonadotropic axis (Furuta et al. 2001, Fernández-Fernández et al. 2004, 2005c, Vulliémoz et al. 2004), the potential contribution of direct pituitary effects of ghrelin in the control of gonadotropin secretion remains scarcely studied, and data so far available evidenced either no effects (Korbonits et al. 2004, van der Lely et al. 2004) or paradoxical stimulatory actions on basal $\mathrm{LH}$ and FSH secretion in prepubertal male rats and in adult cyclic female rats (Fernández-Fernández et al. 2004, 2005c). In this scenario, the aim of present work was to provide further information of the role of ghrelin in the direct control of $\mathrm{LH}$ secretion at pituitary level in prepubertal rats, with special attention to the possible role of ovarian inputs, nitric oxide $(\mathrm{NO})$, and brain sexual differentiation in the control of ghrelin effects on pituitary LH release.

\section{Material and Methods}

\section{Animals and drugs}

Prepubertal (30 days) female Wistar rats were used. The rats were housed (four per cage) under controlled conditions of light (light on from 0500 to $1900 \mathrm{~h}$ ) and temperature $\left(22^{\circ} \mathrm{C}\right)$, with free access to tap water and food available ad libitum. All the experiments were conducted under the approval of the Committee of Animal Experimentation of the University of Córdoba, and in accordance with the NIH Guide for Care and Use of Laboratory Animals.

Ghrelin was obtained from Bachem (Barcelona, Spain). The pure antiestrogen ICI 182780 (7-[9-[4,4,5,5,5penthafluoropentyl)sulfinyl [nonyl]-estra-1,3,5(10)-triene-3,17diol) was obtained from Tocris (Madrid, Spain). $\mathrm{GnRH}, 17 \beta$-estradiol 3-benzoate (EB), and the inhibitor of $\mathrm{NO}$ synthase $\mathrm{N}_{\mathrm{w}}$-nitro-L-arginine methyl ester (L-NAME) were obtained from Sigma. ICI 182780 was dissolved initially in a few drops of dimethylsulfoxide and thereafter was dissolved in saline up to the working concentration; the injection volume was $0.1 \mathrm{ml}$. EB was dissolved in olive oil; the injection volume was $0.1 \mathrm{ml}$. Ghrelin, GnRH, and L-NAME were dissolved in Dulbecco's Modified Eagle's Medium (DMEM; BioWhittaker; Verviers, Belgium) immediately before use.

\section{Experiments}

In order to detect a primary action of ghrelin in the regulation of basal $\mathrm{LH}$ secretion in prepubertal female rats, in Experiment 1, 23-day-old females were ovariectomized or sham-ovariectomized, and 7 days later were humanely killed by decapitation (between 1100 and $1200 \mathrm{~h}$ ). The anterior pituitaries were obtained and placed in glass scintillation vials (one per vial) in a Dubnoff shaker at $37{ }^{\circ} \mathrm{C}$ under an atmosphere of $96 \% \mathrm{O}_{2}-$ $5 \% \mathrm{CO}_{2}$. Each vial contained $1 \mathrm{ml}$ DMEM. After preincubation for $60 \mathrm{~min}$, the medium was replaced by fresh medium alone or containing increasing doses of ghrelin $\left(10^{-9}-10^{-6} \mathrm{M}\right)$. Of note, such a range of doses were selected on the basis of previous references testing direct effects of ghrelin on anterior pituitary secretion (Kojima et al. 1999, Fernández-Fernández et al. 2004, 
2005c). Medium samples were obtained at 60 and $120 \mathrm{~min}$ of the incubation period. Each group was composed of 8-12 pituitaries. On the basis of results from this experiment, an effective dose of ghrelin $10^{-6} \mathrm{M}$ was set for the following experimental settings.

Results from Experiment 1 suggested that in vitro $\mathrm{LH}$ response to ghrelin was modulated by ovarian inputs. Since prepubertal ovaries secrete different steroids and peptides, we decided to analyze the possible selective role of estrogens. Thus, in Experiment 2, prepubertal female rats were subcutaneously injected between day 23 and 29 of age with ICI $182780(150 \mu \mathrm{g} /$ rat per day $)$ or vehicle. The animals were humanely killed by decapitation $24 \mathrm{~h}$ after the last injection, and their pituitaries incubated, as described for Experiment 1, in the presence of DMEM alone or containing $10^{-6} \mathrm{M}$ ghrelin. Medium samples were obtained at 60 and $120 \mathrm{~min}$ of the incubation period. Each group consisted of 10-12 pituitaries. In addition, to analyze the potential role of ovarian inputs other than estrogen, in Experiment 3, 23-day-old female rats were ovariectomized and subcutaneously injected with EB (10 $\mu \mathrm{g} /$ rat per day) or vehicle on days 3,5 , and 7 postovariectomy. The animals were humanely killed by decapitation $24 \mathrm{~h}$ after the last injection and their pituitaries incubated, as described for Experiment 1, in the presence of DMEM alone or $10^{-6} \mathrm{M}$ ghrelin. Medium samples were obtained at 60 and $120 \mathrm{~min}$ of the incubation period. Each group was composed of ten pituitaries.

In order to detect a primary action of ghrelin on $\mathrm{GnRH}$-stimulated $\mathrm{LH}$ secretion in prepubertal female rats, in Experiment 4, 23-day-old females were ovariectomized or sham-ovariectomized, and 7 days later were humanely killed by decapitation and their pituitaries incubated, as described for Experiment 1, in the presence of DMEM alone, ghrelin $\left(10^{-6} \mathrm{M}\right), \mathrm{GnRH}$ $\left(10^{-7} \mathrm{M}\right)$ or ghrelin $\left(10^{-6} \mathrm{M}\right)$ plus $\mathrm{CnRH}\left(10^{-7} \mathrm{M}\right)$. Medium samples were obtained at 60 and 120 min of the incubation period. Each group consisted of 8-12 pituitaries.

Since some of the pituitary effects of ghrelin have been reported to require the presence of $\mathrm{NO}$ (Gaskin et al. 2003, Pinilla et al. 2003), we analyze the potential participation of $\mathrm{NO}$ in the direct stimulatory effect of ghrelin on LH secretion. Thus, in Experiment 5, 23-dayold female rats were ovariectomized, and 7 days later were humanely killed by decapitation and their pituitaries incubated, as described for Experiment 1, in the presence of DMEM alone or medium containing ghrelin $\left(10^{-6} \mathrm{M}\right)$, L-NAME $\left(10^{-4} \mathrm{M}\right)$ or ghrelin $\left(10^{-6} \mathrm{M}\right)$ plus L-NAME $\left(10^{-4} \mathrm{M}\right)$. Medium samples were obtained at 60 and $120 \mathrm{~min}$ of the incubation period. Each group consisted of ten pituitaries.

Finally, in order to detect the influence of brain sexual differentiation on the effects of ghrelin in the control of $\mathrm{LH}$ secretion, in Experiment 6, female rats were subjected to a standard protocol of neonatal estrogenization (100 $\mu \mathrm{g}$
$\mathrm{EB} /$ rat on day 1 , s.c.), and on day 30 post partum, the animals were humanely killed by decapitation, and the hypothalamus and pituitaries were incubated to monitor the effects of ghrelin on $\mathrm{GnRH}$ and $\mathrm{LH}$ secretion respectively. The hypothalami were rapidly excised and dissected out by a horizontal cut of $\sim 2 \mathrm{~mm}$ depth with the following limits: $1 \mathrm{~mm}$ anterior from the optic chiasm, the posterior border of the mamillary bodies, and the hypothalamic fissures. Tissue samples were subsequently incubated in $250 \mu \mathrm{l}$ DMEM, in a Dubnoff shaker incubator under an atmosphere of $95 \% \mathrm{O}_{2}$ and $5 \% \mathrm{CO}_{2}$ at $37.5^{\circ} \mathrm{C}$. After a 30 -min preincubation, the media were removed and the hypothalami were challenged for 30 min with ghrelin $\left(10^{-6} \mathrm{M}\right)$ or medium alone. At the end of incubation period, medium samples were boiled for $30 \mathrm{~min}$ to inactivate endogenous protease activity and stored at $-80{ }^{\circ} \mathrm{C}$ until used for hormone determination. In addition, pituitaries were incubated, as described for Experiment 1, in the presence of DMEM alone or $10^{-6} \mathrm{M}$ ghrelin. Medium samples were obtained at 60 and 120 min of the incubation period. Each group contained 10-12 hypothalami or pituitaries.

\section{LH and GnRH determinations}

$\mathrm{LH}$ levels were measured in $5-50 \mu \mathrm{l}$ samples by a double-antibody method using a RIA kit supplied by NIDDK (Bethesda, MD, USA). Rat LH-I-10 was labeled with $\mathrm{I}^{125}$ using the iodogen method, following the instructions of the manufacturer (Pierce, Rockford, IL, USA) and hormone concentrations were expressed using the RP LH-RP3 as standard. Intra- and interassay variations were 8 and $10 \%$ respectively. The sensitivity of the assay was $5 \mathrm{pg} /$ tube. In addition, GnRH concentrations in the incubation media from hypothalamic explants were measured in $100 \mu \mathrm{l}$ aliquots using a commercial RIA kit purchased from Peninsula Laboratories Inc (Bachem), following the instructions of the manufacturer. The sensitivity of the assay was $1 \mathrm{pg} /$ tube and the intra-assay variation was $<10 \%$. Samples from each experiment were measured in the same assay.

\section{Statistical analysis}

Values are expressed as means ts.E.M. Results were analyzed for statistically significant differences by means of ANOVA followed by Student-Newman-Keuls multiple range test (SigmaStat 2.0, Jandel Corp., San Rafael, CA, USA). In detail, one-way or two-way repeated measures (RM) ANOVA was applied for statistical comparison, as our studies involved subsequent LH determinations at 60 and $120 \mathrm{~min}$ after incubation in the presence of the testing compounds. Specifically, two-way RM ANOVA was used to evaluate the effect of ghrelin in vitro in the presence of additional 
in vivo covariates, such as gonadectomy or steroid treatment. $P \leq 0.05$ was considered significant.

\section{Results}

Role of ovarian inputs in the effects of ghrelin on basal pituitary $\mathbf{L H}$ secretion

The dose-dependent effects of ghrelin on LH secretion directly at the pituitary level were first evaluated. In pituitary samples from intact females, ghrelin significantly stimulated LH secretion only at the dose of $10^{-6} \mathrm{M}$, both at 60 and $120 \mathrm{~min}$ of incubation (Fig. 1A). In contrast, an increased sensitivity in LH responses to ghrelin became apparent after ovariectomy, as significant increases in $\mathrm{LH}$ secretion were observed after challenge with $10^{-8} \mathrm{M}$ (at $120 \mathrm{~min}$ ) and $10^{-7} \mathrm{M}$ (at 60 and $120 \mathrm{~min}$ ) ghrelin of pituitaries from gonadectomized prepubertal rats (Fig. 1B). Due to the accumulative nature of our incubation system, LH levels at 120 min were significantly higher than those at $60 \mathrm{~min}$ in all the experimental groups.


Figure $1 \mathrm{LH}$ concentrations in the media 60 and $120 \mathrm{~min}$ after incubation of pituitaries from 30-day-old intact and ovariectomized female rats. Incubations were carried out in the presence of ghrelin $\left(10^{-9}-10^{-6} \mathrm{M}\right)$ or DMEM alone. Values are expressed as means \pm S.E.M. ( $n=8-12$ /group). ${ }^{* *} P \leq 0.01$ versus DMEM at the corresponding time-point; ${ }^{\text {a }} P \leq 0.01$ versus corresponding values at 60 min (one-way RM ANOVA followed by Student-Newman-Keuls multiple range test).
To further explore the involvement of ovarian signals in the modulation of pituitary responsiveness to ghrelin, in vitro tests were conducted using pituitaries from rats treated with the antiestrogen ICI 182780 or gonadectomized and supplemented with estradiol. Treatment with ICI 182780 was effective to block endogenous estrogen action, since serum LH concentrations were significantly increased at the end of treatment regimen $(2.46 \pm 0.44$ vs $0.13 \pm 0.01 \mathrm{ng} / \mathrm{ml} ; P \leq 0.01)$. In keeping with results from Experiment 1, $10^{-6} \mathrm{M}$ ghrelin significantly stimulated $\mathrm{LH}$ release in vitro, at 60 and $120 \mathrm{~min}$, by pituitaries from vehicle- and ICI $182780-$ treated animals (Fig. 2A). However, the magnitude of $\mathrm{LH}$ responses to ghrelin was significantly augmented in the ICl-treated group, at 60 and 120 min of incubation period (Fig. 2A).

In turn, analysis of $\mathrm{LH}$ responses to ghrelin in pituitaries from ovariectomized rats, replaced or not with estradiol, revealed that ghrelin elicited LH release by pituitaries from ovariectomized and ovariectomized+estradiol-treated female rats (Fig. 2B). The effectiveness of estradiol treatment in this setting was confirmed by the decrease in serum LH concentrations in terminal trunk blood samples $(1.49 \pm 0.24$ vs $16.83 \pm$ $1.26 \mathrm{ng} / \mathrm{ml}$ in ovariectomized rats; $P \leq 0.01)$. Of note, pituitaries from ovariectomized(estradiol-treated rats released significantly more $\mathrm{LH}$ than pituitaries from ovariectomized animals treated with vehicle (Fig. 2B). Given these 'basal' differences, in addition to net (absolute) responses, the effects of ghrelin on $\mathrm{LH}$ secretion were also expressed as percentage of increase over corresponding control values from pituitaries incubated with medium alone. As shown in Fig. 3, relative $\mathrm{LH}$ responses to ghrelin appeared increased after ovariectomy, slightly decreased after estradiol replacement, and clearly enhanced after blockade of endogenous estrogen by ICl 182780 .

\section{Effect of ghrelin on GnRH-stimulated LH secretion}

The interplay between ghrelin and GnRH secretion was explored in prepubertal female rats. GnRH-stimulated $\mathrm{LH}$ release by pituitaries from intact and ovariectomized females, at 60 and 120 min of the incubation (Fig. 4). The stimulatory effect of $\mathrm{GnRH}$ was potentiated by ghrelin in pituitaries obtained from intact and ovariectomized females (Fig. 4), a phenomenon that was significant at $120 \mathrm{~min}$ in the intact group, and at both 60 and $120 \mathrm{~min}$ of incubation in ovariectomized rats (Fig. 4).

\section{Role of NO in the stimulatory effect of ghrelin on $\mathrm{LH}$ secretion}

Blockade of endogenous NO synthases by L-NAME had no effect on $\mathrm{LH}$ secretion by pituitaries from ovariectomized rats. However, the stimulatory effect of ghrelin 

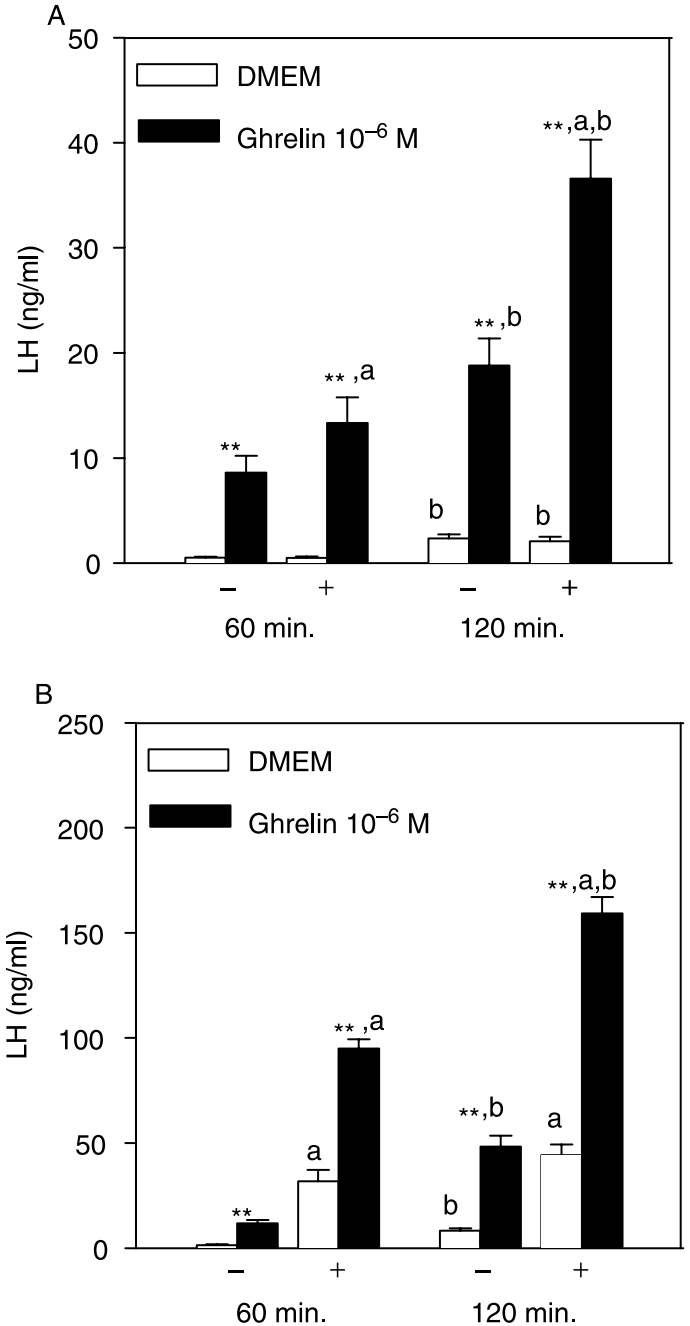

Figure $2 \mathrm{~A}$ (upper panel) LH concentrations in the media 60 and $120 \mathrm{~min}$ after incubation of pituitaries from 30-day-old intact female rats treated between days 23 and 30 with vehicle (-) or ICI $182780(+)(150 \mu \mathrm{g} / \mathrm{rat}$ per day). B (lower panel) LH concentrations in the media 60 and 120 min after incubation of pituitaries from 31-day-old ovariectomized female rats. Ovariectomy was carried out on day 23 and ovariectomized rats were treated on days 26,28 , and 30 with vehicle $(-)$ or estradiol benzoate $(+)(10 \mu \mathrm{g} /$ rat per day). Incubations were carried out in the presence of ghrelin $\left(10^{-6} \mathrm{M}\right.$; solid bars) or DMEM alone (open bars). Values are expressed as means \pm s.E.M. $\left(n=10-12\right.$ /group. ${ }^{* *} P \leq 0.01$ versus DMEM, ${ }^{\mathrm{a}} P \leq 0.01$ versus corresponding animals not treated with ICI 182780 or estradiol benzoate in vivo; ${ }^{\mathrm{b}} P \leq 0.01$ versus corresponding values at $60 \mathrm{~min}$ (two-way RM ANOVA followed by StudentNewman-Keuls multiple range test).

on $\mathrm{LH}$ secretion was blunted in the presence of L-NAME, at 60 and $120 \mathrm{~min}$ of the incubation period (Fig. 5).

\section{Effects of neonatal estrogenization on ghrelin effects on GnRH and $L H$ secretion}

Female rats subjected to neonatally estrogenization showed a significant reduction in ovarian weights and serum LH levels on day 30 post partum (Table 1).

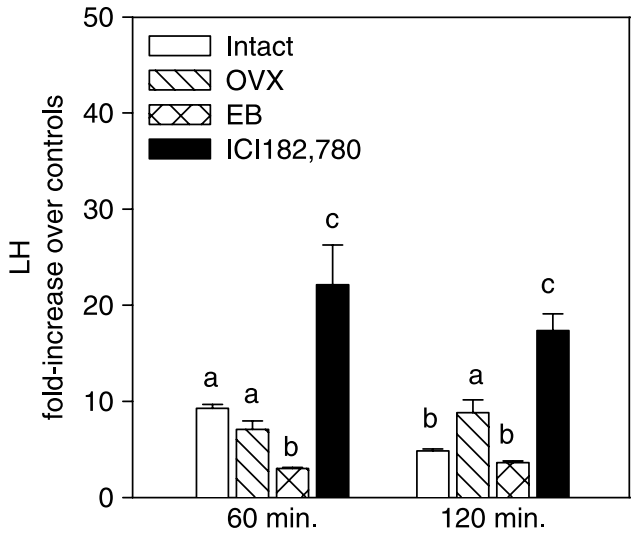

Figure 3 Effects of ghrelin $\left(10^{-6} \mathrm{M}\right)$ on $\mathrm{LH}$ release after 60 and $120 \mathrm{~min}$ of the incubation period from intact, ovariectomized (OVX), OVX plus estradiol benzoate (EB) or intact rats treated with ICI 182780 . Values are expressed as percentage of increase over LH concentrations measured in absence of ghrelin. Groups with different superscript letters them are statistically different (ANOVA followed by StudentNewman-Keuls multiple range test).

Ghrelin, at the dose of $10^{-6} \mathrm{M}$, was unable to modify $\mathrm{GnRH}$ release by hypothalamic explants from control or neonatally estrogenized female rats ex vivo (Table 2). Concerning pituitary effects, in vitro basal pituitary LH secretion was significantly reduced in neonatally estrogenized female rats. Yet, the ability of ghrelin to induce significant stimulatory responses in terms of LH secretion was persistently observed in estrogenized female rats, at 60 and $120 \mathrm{~min}$ of incubation. Nonetheless, in this experiment, statistical analyses by two-way RM ANOVA, using in vivo treatment (with or without estradiol) and in vitro conditions (with or without ghrelin) as variables, evidenced that, at both 60 and 120 min of incubation, the response to ghrelin was attenuated in EB-treated female rats (Fig. 6).

\section{Discussion}

Our present results reinforce previously published data pointing out that ghrelin conducts specific regulatory effects upon the GnRH/LH axis (Barreiro \& Tena-Sempere 2004); yet, they provide novel evidence for the multifaceted mode of action of ghrelin on the gonadotropic system. The most relevant findings of the present experiments can be summarized as follows: (1) ghrelin consistently stimulated pituitary LH secretion in vitro in a wide diversity of experimental conditions in prepubertal female rats; (2) the sensitivity to ghrelin, expressed as either the minimal effective dose or the amplitude of $\mathrm{LH}$ responses, was modulated by ovarian inputs; (3) the blockade of estrogen action significantly augmented the stimulatory effect of ghrelin; (4) the stimulatory effect of ghrelin on LH secretion required proper NO synthesis; 

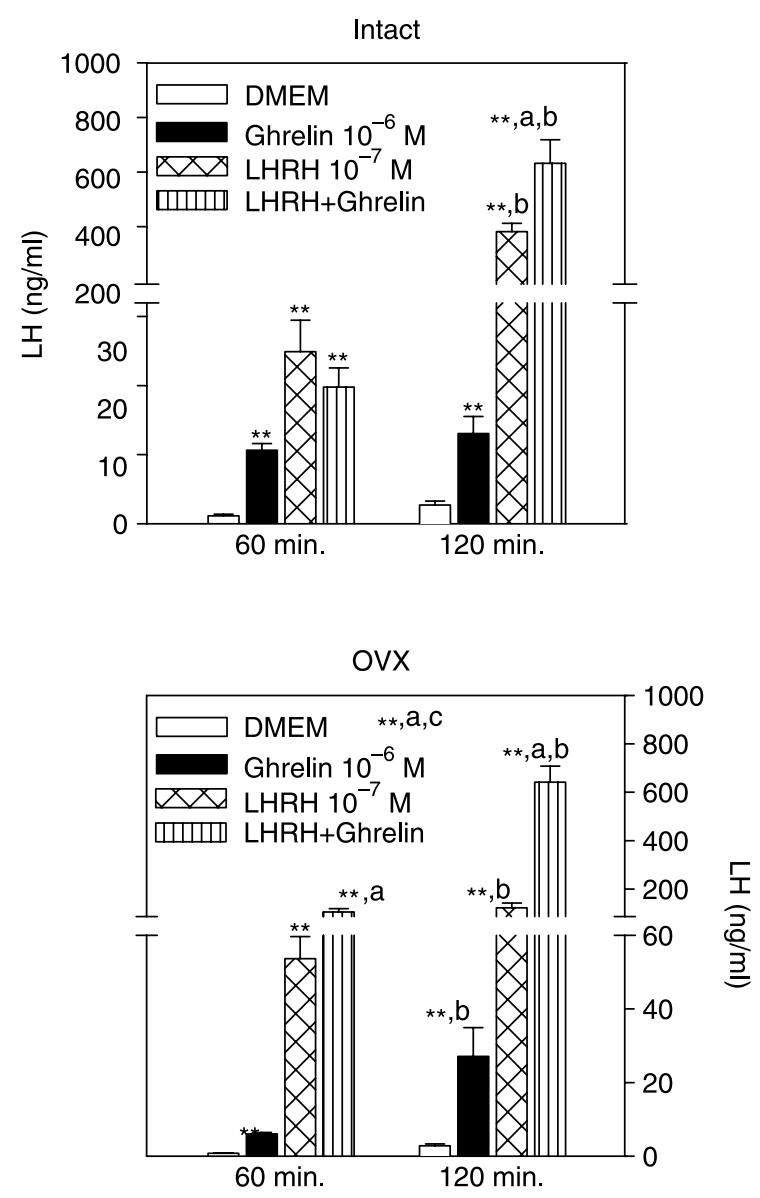

Figure $4 \mathrm{LH}$ concentrations in the media 60 and $120 \mathrm{~min}$ after incubation of pituitaries from intact (left panel) and ovariectomized (right panel) females. Incubations were carried out in the presence of DMEM, ghrelin $\left(10^{-6} \mathrm{M}\right), \mathrm{GnRH}\left(10^{-7} \mathrm{M}\right)$, or ghrelin $+\mathrm{GnRH}$. Values are expressed as means \pm s.E.M. $\left(n=8-12\right.$ /group). ${ }^{* *} P \leq 0.01$ versus corresponding DMEM groups, ${ }^{\mathrm{a}} P \leq 0.01$ versus corresponding groups challenged with $\mathrm{GnRH}$ alone; ${ }^{b} P \leq 0.01$ versus corresponding values at 60 min (one-way RM ANOVA followed by Student-Newman-Keuls multiple range test).

and (5) ghrelin did not alter hypothalamic GnRH secretion in vitro in prepubertal female rat and its ability to stimulate pituitary $\mathrm{LH}$ secretion in vitro was preserved after neonatal estrogenization. The range of doses of ghrelin used in the present study was selected on the basis of previous studies testing its effects on anterior pituitary secretion (Kojima et al. 1999, Fernández-Fernández et al. 2004, 2005c). Of note, ghrelin input on the pituitary in physiologic conditions might theoretically derive from three different sources, i.e. systemic gut-derived ghrelin, hypothalamic-released peptide and locally produced ghrelin (Kojima et al. 1999, Caminos et al. 2003, Korbonits et al. 2004). This fact, together with potential tissue-specific changes in ghrelin expression depending on the stage of development, metabolic cues and pathologic conditions (van der Lely et al. 2004), make it difficult to estimate the actual ghrelin burden on the



Figure $5 \mathrm{LH}$ concentrations in the media 60 and $120 \mathrm{~min}$ after incubation of pituitaries from 30-day-old ovariectomized rats in the presence of DMEM, ghrelin $\left(10^{-6} \mathrm{M}\right)$, L-NAME $\left(10^{-4} \mathrm{M}\right)$, or ghrelin + L-NAME. Ovariectomy was carried out on day 23. Values are expressed as means \pm s.E.M. ( $n=10 /$ group). ${ }^{* *} P \leq 0.01$ versus DMEM at the corresponding time-point; ${ }^{a} P \leq 0.01$ versus corresponding values at 60 min (one-way RM ANOVA followed by Student-Newman-Keuls multiple range test).

pituitary, but it is likely that its local levels are (much) higher than those detected in circulation.

Ghrelin effects on $\mathrm{GnRH} / \mathrm{LH}$ release appear to be age and sex dependent. Thus, detail comparison with previously reported data in adult cyclic rats (Fernández-Fernández et al. 2005c) identifies two clear differences: (i) ghrelin inhibits $\mathrm{GnRH}$ release in adult but not in prepubertal female rats and (ii) ghrelin blunts $\mathrm{GnRH}$ stimulated LH-stimulated secretion in adult female rats, but apparently potentiates it in prepubertal females. Assumedly, elucidation of the mechanisms for these differences, and their possible role in pubertal development, need further studies. Nonetheless, it is to be stressed that previous evidence has strongly suggested the potential involvement of ghrelin in the regulation of the gonadotropic axis at puberty in the rat (Fernández-Fernández et al. 2005b, Martini et al. 2006).

In previous studies, we have demonstrated that ghrelin stimulates gonadotropin secretion by pituitaries from intact prepubertal male rats (Fernández-Fernández et al. 2004) and adult cyclic females (Fernández-Fernández et al. 2005c). Present data showed that ghrelin consistently stimulates pituitary LH secretion in different prepubertal female models such as intact animals,

Table 1 Luteinizing hormone (LH) concentrations and ovarian weights in 30-day-old female rats injected on day 1 with vehicle or estradiol benzoate (females: $100 \mu \mathrm{g} /$ rat; males: $500 \mu \mathrm{g} / \mathrm{rat}$ ).

\begin{tabular}{lcc}
\hline Treatment & LH $(\mathrm{ng} / \mathrm{ml})$ & Ovary $(\mathrm{mg})$ \\
\hline Vehicle & $0.69 \pm 0.19(21)$ & $7.54 \pm 0.20(25)$ \\
EB & $0.12 \pm 0.01(21)^{*}$ & $1.27 \pm 0.09(25)^{*}$
\end{tabular}

Values are expressed as means \pm s.E.M. Number of animals per group are indicated in parentheses. ${ }^{*} P \leq 0.01$ (Student's test). 
Table 2 Effects of ghrelin $\left(10^{-6} \mathrm{M}\right)$ on gonadotrophin-releasing hormone $(\mathrm{GnRH})$ release $(\mathrm{pg} /$ hypothalamus/30 $\mathrm{min}$ ) by hypothalamic explants obtained in 30-day-old females rats neonatally injected on day 1 of life with vehicle or estradiol benzoate (100 $\mu \mathrm{g} / \mathrm{rat})$.

\begin{tabular}{lcc}
\hline & EMEM & Ghrelin \\
\hline Control females & $5.92 \pm 0.62(11)$ & $6.97 \pm 0.87(12)$ \\
Estrogenized females & $4.40 \pm 0.57(11)$ & $6.80 \pm 1.00(12)$ \\
\hline
\end{tabular}

Values are expressed as means \pm S.E.M. Number of determination per group are indicated in parentheses. ${ }^{*} P \leq 0.01$ (Student's test).

females treated with an antiestrogen, ovariectomized females submitted or not to estradiol replacement, and in intact females subjected to an effective protocol of neonatal estrogenization. These results evidence that the ability of ghrelin to elicit LH secretion directly at the pituitary level can manifest regardless of the prevailing pituitary LH content, the ovarian inputs, and the neonatal steroid milieu. It is worthy noting that ghrelin has been reported to increase LH secretion also by dispersed pituitary cells from the goldfish (Unniappan \& Peter 2004), suggesting the conservation of this function during evolution.

Previous studies have repeatedly indicated that the effects of different factors involved in the control of $\mathrm{LH}$ secretion are dependent on the steroid milieu. For instance, the stimulation of $\mathrm{LH}$ secretion after activation of receptors for excitatory amino acids with N-methyl-Daspartic acid (NMDA; as agonist of NMDA receptors) or AMPA (as agonist of non-NMDA receptors) requires the presence of estradiol (Brann \& Mahesh 1995, Ping et al. 1997, González et al. 1999a). Our present results point out that the stimulatory effect of ghrelin on LH secretion at pituitary level is influenced by ovarian inputs. This

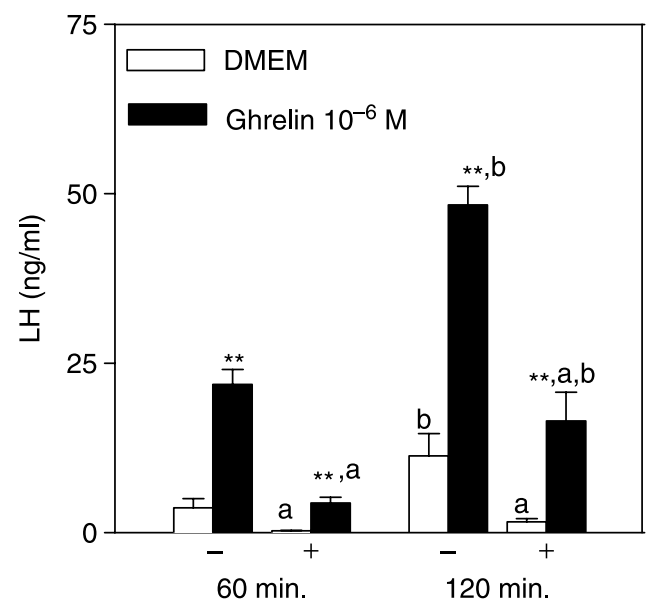

Figure 6 LH concentrations in the media 60 and 120 min after incubation of pituitaries with DMEM (open bars) or ghrelin $\left(10^{-6} \mathrm{M}\right.$; hatched bars). Female rats were injected on day 1 with vehicle $(-)$ or estradiol benzoate (+). Values are expressed as means \pm S.E.M. ( $n=10-12$ /group). ${ }^{* *} P \leq 0.01$ versus DMEM alone, ${ }^{a} P \leq 0.01$ versus non-estrogenized animals;

${ }^{\mathrm{b}} P \leq 0.01$ versus corresponding values at $60 \mathrm{~min}$ (two-way RM ANOVA followed by Student-Newman-Keuls multiple range test). contention is suggested by the increase in the sensitivity to ghrelin after ovariectomy and the blockade of endogenous estrogen by $\mathrm{ICl}$ treatment, as well as by the decrease in the responsiveness to ghrelin observed in ovariectomized-estradiol-treated females. The precise mechanism(s) whereby estrogen modulates pituitary responsiveness to ghrelin remain to be elucidated as, in principle, such an effect might derive from direct pituitary actions of estrogen and/or indirect effects mediated by changes in the prevailing $\mathrm{GnRH}$ input in vivo. In addition, the potential contribution of changes in the pituitary content of LH cannot be ruled out. Nonetheless, our current observations on the influence of estrogen on $\mathrm{LH}$ responses are in good agreement with the changes in pituitary responsiveness to ghrelin along the estrous cycle, as reported recently by our group (Fernández-Fernández et al. 2005c).

Present results are somewhat opposite to those previously reported by our group on the effects of ovarian inputs upon ghrelin effects on $\mathrm{LH}$ secretion (Fernández-Fernández et al. 2005c). Thus, in adult females, ovariectomy abolished the direct stimulatory effect of ghrelin on basal LH secretion; estradiol replacement being unable to rescue ghrelin effects (Fernández-Fernández et al. 2005c). In contrast, in prepubertal females (present experiments), ovariectomy, as well as treatment with a selective antiestrogen, were followed by an increase in the pituitary sensitivity to ghrelin action. Such age difference may be consequence of the different functionality of the prepubertal and adult ovary. Alternatively, changes in pituitary function along lifespan may also account for such a divergence. Indeed, prepubertal and adult pituitary differs in the morphological features of LH-secreting cells (Bello-Pineda et al. 1999), as well as in relative expression levels of ghrelin and GHS-R mRNAs. On the latter, expression of both genes at the pituitary is significantly higher in prepubertal than in adult male and female rats (Kamegai et al. 1999, Torsello et al. 2003).

The mechanism(s) involved in the stimulatory effect of ghrelin at the pituitary level remains unknown. In this context, a key issue is whether ghrelin action is primarily conducted directly on gonadotrops or, alternatively, via other pituitary cells, which may conduct paracrine actions upon gonadotrops. The cellular localization of ghrelin receptor at the pituitary has not been clearly established, and analyses on the regulation of GHS receptors at this site have been solely conducted in whole pituitary tissue (McKee et al. 1997, Kamegai et al. 1999, Kineman et al. 1999, Horikawa et al. 2000, Katayama et al. 2000, Nass et al. 2000). If GHS receptors are absent in gonadotrops, it should be assumed that the effects of ghrelin on LH secretion are exerted via a paracrine action, using one or some of the plethora of signals involved in intercellular communication at the pituitary (Schwartz 2000). Indeed, we have proposed previously the possibility that NO could mediate the 
effect of ghrelin on LH secretion, since NO conducts direct stimulatory actions on $\mathrm{LH}$ and FSH secretion through a calcium-dependent, cGMP-independent mechanism (Pinilla et al. 1998), and it appears to mediate other relevant ghrelin actions, such as those on $\mathrm{GH}$ release (Pinilla et al. 2003), vascular relaxation (Shimizu et al. 2003), and food intake (Gaskin et al. 2003). In addition, hypothalamic NO synthases are increased by ghrelin (Gaskin et al. 2003). Present experiments support this possibility, since blockade of NO synthase with L-NAME abolished the stimulatory action of ghrelin on LH secretion. However, the cellular source of $\mathrm{NO}$ required for the expression of ghrelin action remains to be elucidated.

Our previous data demonstrated that ghrelin blunted LH responses to $\mathrm{GnRH}$ in adult rats regardless of the stage of cycle (Fernández-Fernández et al. 2005c). Present experiments showed, in contrast, that in intact and ovariectomized prepubertal rats ghrelin potentiated the stimulatory effect of GnRH on LH secretion. In addition, our data also indicate that this effect is augmented after ovariectomy, which suggests that ovarian inputs are involved in the modulation of ghrelin effects upon the responsiveness of $\mathrm{LH}$ to $\mathrm{GnRH}$; an event already described in adult females (Fernández-Fernández et al. 2005c). The mechanism (s) whereby ghrelin is capable to modulate the stimulatory effect of $\mathrm{GnRH}$ on $\mathrm{LH}$ secretion is unknown. It might be possible that ghrelin participates in the tuning of $\mathrm{GnRH}$ binding to its own receptor or, alternatively, the intracellular actions of $\mathrm{GnRH}$, as described previously for other peptides involved in the control of GnRH action, such as NPY (Parker et al. 1991, Evans 1999), galanin (Parker et al. 1991), or endothelins (Kauyicska et al. 1991). Considering that the intracellular signaling of $\mathrm{GnRH}$ and ghrelin is mediated by the same family of $\mathrm{G}$ proteins (Naor et al. 2000, Liu et al. 2002, Kojima \& Kangawa 2005), a crosstalk between both signals is plausible, a possibility that is presently under evaluation at our laboratory.

In conclusion, present experiments evidenced a direct stimulatory effect of ghrelin on pituitary LH secretion in prepubertal female rats. This stimulatory effect was increased in the absence of estrogenic inputs and was mediated by NO. Overall, these data reinforce the concept that ghrelin participates in the control of pituitary hormones other than $\mathrm{GH}$ (van der Lely et al. 2004, Tena-Sempere et al. 2004), and suggest the involvement of ovarian signals in the modulation of the effects of ghrelin on LH secretion at the pituitary level.

\section{Acknowledgements}

This work was supported by grant BFU 2005-07446 from DGESIC (Ministerio de Ciencia y Tecnología. Spain), CIBER Physiopathology of Obesity and Nutrition (ISCiii, Ministerio de Sanidad, Spain), and Junta de Andalucia (Consejería de Innovación, Ciencia y Empresa). The authors are indebted to Eva Vigo and Rafael Pineda for superb assistance in completion of some of the experiments included in the present study. RIA kits for hormone determinations were kindly supplied by Dr AF Parlow (National Institute of Diabetes and Digestive and Kidney Diseases, National Hormone and Peptides Program, Torrance, CA, USA). The authors declare that there is no conflict of interest that would prejudice the impartiality of this scientific work.

\section{References}

Ahima RS, Saper CB, Flier JS \& Elmquist JK 2000 Leptin regulation of neuroendocrine system. Frontiers in Neuroendocrinology 21 263-307.

Ahnfelt-Ronne I, Nowak J \& Olsen UB 2001 Do growth hormonereleasing peptides act as ghrelin secretagogues? Endocrine $\mathbf{1 4}$ 133-135.

Arvat E, Gianotti L, Giordano R, Broglio F, Maccario M, Lanfranc F, Muccioli G, Papotti M, Graziani A, Ghigo E, et al. 2001 a Growth hormone-releasing hormone and growth hormone secretagoguereceptor ligands: focus on reproductive system. Endocrine 14 35-43.

Arvat E, Maccario M, Di Vito L, Broglio F, Benso A, Cottero C, Papotti M, Muccioli G, Dieguez C, Casanueva FF, et al. 2001b Endocrine activities of ghrelin, a natural growth hormone secretagogue (GHS) in humans: comparison and interactions with hexarelin, a nonnatural peptidyl GHS, and GH-releasing hormone. Journal of Endocrinology and Metabolism 86 1169-1174.

Barraclough CA 1961 Production of anovulatory sterile rat by single injections of testosterone propionate. Endocrinology 68 62-67.

Barreiro ML \& Tena-Sempere M 2004 Ghrelin and reproduction: a novel signal linking energy status and fertility. Molecular and Cellular Endocrinology 226 1-9.

Barreiro ML, Gaytán F, Caminos JE, Pinilla L, Casanueva FF, Aguilar E, Diéguez C \& Tena-Sempere M 2002 Cellular location and hormonal regulation of ghrelin expression in rat testis. Biology of Reproduction 67 1768-1776.

Barreiro ML, Suominen JS, Gaytán F, Pinilla L, Chopin LK, Casanueva FF, Diéguez C, Aguilar E, Toppari M \& Tena-Sempere M 2003 Developmental, stage-specific and hormonally regulated expression of growth hormone secretagogue receptor messenger RNA in rat testis. Biology of Reproduction 68 1631-1640.

Bellido C, Gaytán F, Aguilar R, Pinilla L \& Aguilar E 1985 Prepuberal reproductive defects in neonatal estrogenized male rats. Biology of Reproduction 33 381-387.

Bello-Pineda J, Luna J, Romano MC \& Mendoza ME 1999 Developmental changes in $\mathrm{LH}$ secretion by male pituitaries in vitro from the infantile to adult period. Journal of Endocrinology $\mathbf{1 6 0}$ 333-341.

Brann DW \& Mahesh VB 1995 Glutamate: a major neuroendocrine excitatory signal mediating steroid effects on gonadotropin secretion. Journal of Steroid Biochemistry and Molecular Biology 53 325-329.

Camina JP, Carreira MC, Micic D, Pombo M, Kelestimur F, Dieguez C \& Casanueva FF 2003 Regulation of ghrelin secretion and action. Endocrine 22 5-12.

Caminos JE, Nogueiras R, Blanco M, Seoane LM, Bravo S, Alvarez CV, Garcia-Caballero T, Casanueva FF \& Dieguez C 2003 Cellular distribution and regulation of ghrelin messenger ribonucleic acid in the rat pituitary gland. Endocrinology 144 5089-5097.

Casanueva FF \& Diéguez C 1999 Neuroendocrine regulation and actions of leptin. Frontiers in Neuroendocrinology 20 317-363.

Evans JJ 1999 Modulation of gonadotropin levels by peptides acting at the anterior pituitary gland. Endocrine Reviews 20 46-67.

Fernández-Fernández R, Tena-Sempere M, Aguilar E \& Pinilla L 2004 Ghrelin effects on gonadotropin secretion in male and female rats. Neuroscience Letters 362 103-107. 
Fernández-Fernández $R$, Aguilar E, Tena-Sempere $M$, FernándezFernández R, Aguilar E, Tena-Sempere M \& Pinilla L 2005a Effects of polypeptide $\mathrm{YY}_{3-36}$ upon luteinizing hormone-releasing hormone and gonadotropin secretion in prepubertal rats: in vivo and in vitro studies. Endocrinology 146 1403-1410.

Fernández-Fernández $R$, Navarro $V M$, Barreiro $M L$, Vigo EM, Tovar S, Sirotkin AV, Casanueva FF, Aguilar E, Diéguez C, Pinilla L, et al. 2005b Effects of chronic hyperghrelinemia on puberty onset and pregnancy outcome in the rat. Endocrinology 146 3018-3025.

Fernández-Fernández $R$, Tena-Sempere $M$, Navarro $V$, Barreiro $M L$, Vigo E, Aguilar E \& Pinilla L 2005c Effects of ghrelin upon gonadotropin-releasing hormone and gonadotropin secretion in adult female rats: in vivo and in vitro studies. Neuroendocrinology 82 245-255.

Fernández-Fernández R, Martini AC, Navarro VM, Castellano JM, Dieguez C, Aguilar E, Pinilla L \& Tena-Sempere M 2006 Novel signals for the integration of energy balance and reproduction. Molecular and Cellular Endocrinology 254-255 127-132.

Furuta M, Funabashi T \& Kimura F 2001 Intracerebroventricular administration of ghrelin rapidly suppresses pulsatile luteinizing hormone secretion in ovariectomized rats. Biochemical and Biophysical Research Communications 288 780-785.

Gaskin FS, Farr SA, Banks WA, Kumar VB \& Morley JE 2003 Ghrelininduced feeding is dependent on nitric oxide. Peptides 24 913-918.

Gaytán F, Barreiro ML, Chopin LK, Herington AC, Morales C, Pinilla L, Casanueva FF, Aguilar E, Diéguez C \& Tena-Sempere M 2003 Immunolocalization of ghrelin and its functional receptor, type $1 \mathrm{a}$ growth hormone secretagogue receptor, in the cyclic human ovary. Journal of Clinical Endocrinology and Metabolism 88 879-887.

Gaytán F, Barreiro ML, Caminos JE, Chopin LK, Herington AC, Morales C, Pinilla L, Paniagua R, Nistal M, Casanueva FF, et al. 2004 Expression of ghrelin and its functional receptor, the type 1a growth hormone secretagogue receptor, in normal human testis and testicular tumors. Journal of Clinical Endocrinology and Metabolism 89 400-409.

Ghigo E, Arvat E, Giordano R, Broglio F, Gianotti L, Maccario M, Bisi G, Graziani A, Papotti M, Muccioli G, et al. 2001 Biological activities of growth hormone secretagogues in humans. Endocrine 14 87-93.

González LC, Pinilla L, Tena-Sempere M \& Aguilar E 1999a Role of alphaamino-3-hydroxy-5-methylisoxazole-4-propionic acid receptors in the control of prolactin, growth hormone and gonadotropin secretion in prepubertal rats. Journal of Endocrinology 162 417-424.

Gorski RA 1963 Modification of ovulatory mechanisms by postnatal administration of estrogen to the rats. American Journal of Physiology 205 842-844.

Gorski RA 1990 Sexual differences of the brain: comparative aspects. In Control of the Onset of Puberty, pp 231-250. Eds MM Grumbach, PC Sizonenko \& ML Aubert. Baltimore: Williams \& Wilkins.

Gualillo O, Caminos JE, Blanco M, García-Caballero T, Kojima M, Kangawa K, Diéguez C \& Casanueva FF 2001 Ghrelin, a novel placental-derived hormone. Endocrinology 142 788-794.

Hataya Y, Akamizu T, Takaya K, Kanamoto N, Ariyasu H \& Saijo M 2001 A low dose of ghrelin stimulates growth hormone $(\mathrm{GH})$ release synergistically with $\mathrm{GH}$-releasing hormone in humans. Journal of Clinical Endocrinology and Metabolism 864552.

Horikawa R, Tachibana T, Katsumata N, Ishikawa H \& Tanaka T 2000 Regulation of pituitary growth hormone-secretagogue and growth hormone-releasing hormone receptor RNA expression in young Dwarf rats. Endocrinology Japanese 47 S53-S56.

Howard AD, Feighner SC, Cully DF, Arena JP, Liberator PA, Rosenblum Cl, Hamelin M, Hreniuk DL, Palyha OC, Anderson J, et al. $1996 \mathrm{~A}$ receptor in pituitary and hypothalamus that functions in growth hormone release. Science 273 974-977.

Kamegai J, Wakabayashi I, Kineman RD \& Frohman LA 1999 Growth hormone-releasing hormone receptor (GHRH-R) and growth hormone secretagogue receptor (GHS-R) mRNA levels during postnatal development in male and female rats. Journal of Neuroendocrinology 11 299-306.

Katayama M, Nogami H, Nishiyama J, Kawase T \& Kawamura K 2000 Developmentally and regionally regulated expression of growth hormone secretagogue receptor mRNA in rat brain and pituitary gland. Neuroendocrinology 72 333-340.

Kauyicska B, Burris TP \& Freeman ME 1991 The effects of endothelins on the secretion of prolactin, luteinizing hormone, and folliclestimulating hormone are mediated by different guanine nucleotidebinding proteins. Endocrinology 129 2607-2613.

Kawamura K, Sato N, Fukuda J, Kodama H, Kumegai J, Tanikawa H, Nakamura A, Honda Y, Sato T \& Tanaka T 2003 Ghrelin inhibits the development of mouse preimplantation embryos in vitro. Endocrinology 144 2623-2633.

Kineman RD, Kamegai J \& Frohman LA 1999 Growth hormone (GH)releasing hormone $(\mathrm{GHRH})$ and the $\mathrm{GH}$ secretagogue $(\mathrm{GHS})$ L692,585, differentially modulate rat pituitary GHS receptor and GHRH receptor messenger ribonucleic acid levels. Endocrinology 140 3581-3586.

Kogawa K, Nakamura T, Sugino K, Takio K, Titani K \& Sugino H 1991 Activin binding protein is present in pituitary. Endocrinology $\mathbf{1 2 8}$ 1434-1440.

Kojima M \& Kangawa K 2005 Ghrelin: structure and function. Physiological Reviews 85 495-522.

Kojima M, Hosoda H, Date Y, Nakazato M, Matsuo H \& Kangawa K 1999 Ghrelin is a growth-hormone releasing acylated peptide from stomach. Nature $\mathbf{4 0 2}$ 656-660.

Kojima M, Hosoda H, Matsuo H \& Kangawa K 2001 Ghrelin: discovery of the natural endogenous ligand for the growth hormone secretagogue receptor. Trends in Endocrinology \& Metabolism 12 118-122.

Korbonits M, Goldstone AP, Gueorguiev M \& Grossman AB 2004 Ghrelin-a hormone with multiple functions. Frontiers in Neuroendocrinology 25 27-68.

van der Lely AJ, Tschöp M, Heiman ML \& Ghigo E 2004 Biological, physiological, pathophysiological, and pharmacological aspects of ghrelin. Endocrine Reviews 25 426-457.

Liu F, Usui I, Evans LG, Austin DA, Mellon PL, Olefsky JM \& Webster NJ 2002 Involvement of both $\mathrm{G}(\mathrm{q} / 11)$ and $\mathrm{G}(\mathrm{s})$ proteins in gonadotropin-releasing hormone receptor-mediated signaling in $\mathrm{L} \beta$ T2 cells. Journal of Biological Chemistry 277 32099-32108.

Martini AC, Fernández-Fernández R, Tovar S, Navarro VM, Vigo E, Vazquez MJ, Davies JS, Thompson NM, Aguilar E, Pinilla L, et al. 2006 Comparative analysis of the effects of ghrelin and unacylated ghrelin on luteinizing hormone secretion in male rats. Endocrinology 147 2374-2382.

McKee KK, Palyha OC, Feighner SD, Hreniuk DL, Tan CP, Phillips MS, Smith RG, van der Ploeg LH \& Howard AD 1997 Molecular analysis of rat pituitary and hypothalamic growth hormone secretagogue receptors. Molecular Endocrinology 11 415-423.

Meunier H, Rivier C, Evans RM \& Vale W 1988 Gonadal and extragonadal expression of inhibin $\alpha, \beta A$ and $\beta B$ subunits in various tissues predicts diverse functions. PNAS 85 247-251.

Misra M, Millar KK, Kuo K, Griffin K, Stewart V, Hunter E, Herzog DB \& Klibanski A 2005 Secretory dynamics of ghrelin in adolescent girls with anorexia nervosa and healthy adolescents. American Journal of Physiology Endocrinology and Metabolism 289 E347-E356.

Moore JP, Wilson L, Dalkin AC \& Winters SJ 2003 Differential expression of the pituitary gonadotropin subunit genes during male rat sexual maturation: reciprocal relationship between hypothalamic pituitary adenylate cyclase-activating polypeptide and folliclestimulating hormone $\beta$ expression. Biology of Reproduction 69 234-241.

Naor Z, Benard O \& Seger R 2000 Activation of MAPK cascades by G-protein-coupled receptors: the case of gonadotropin-releasing hormone receptor. Trends in Endocrinology and Metabolism 11 91-99. 
Nass R, Gilrain J, Anderson S, Gaylinn B, Dalkin A, Day R, Peruggia M \& Thorner MO 2000 High plasma growth hormone $(\mathrm{GH})$ levels inhibit expression of $\mathrm{GH}$ secretagogue receptor messenger ribonucleic acid levels in rat pituitary. Endocrinology 141 2084-2089.

Parker SL, Kalra SP \& Crowley WR 1991 Neuropeptide Y modulates the binding of a gonadotropin-releasing hormone $(\mathrm{GnRH})$ analog to anterior pituitary $\mathrm{GnRH}$ receptor sites. Endocrinology $\mathbf{1 2 8}$ 2309-2316.

Ping L, Mahesh VB, Bhat GK \& Brann DW 1997 Regulation of gonadotropin-releasing hormone and luteinizing hormone secretion by AMPA receptors. Evidence for a physiological role of AMPA receptors in the steroid-induced luteinizing hormone surge. Neuroendocrinology 66 246-253.

Pinilla L, Garnelo P, Gaytán F \& Aguilar E 1992 Hypothalamic-pituitary function in neonatally oestrogen-treated male rats. Journal of Endocrinology 134 279-286.

Pinilla L, González D, Tena-Sempere M \& Aguilar E 1998 Nitric oxide (NO) stimulates gonadotropin secretion through a calcium-dependent, cGMP independent mechanism. Neuroendocrinology 68 180-186.

Pinilla L, Barreiro ML, Tena-Sempere M \& Aguilar E 2003 Role of ghrelin in the control of growth hormone secretion in prepubertal rats: interactions with excitatory amino acids. Neuroendocrinology 77 83-90.

Pu S, Jain MR, Kalra PS \& Kalra SP 1998 Orexins, a novel family of hypothalamic neuropeptides, modulate pituitary luteinizing hormone secretion in an ovarian steroid-dependent manner. Regulatory Peptides 78 133-136.

Schwartz J 2000 Intercellular communication in the anterior pituitary. Endocrine Reviews 21 488-513.

Seoane IM, Tovar S, Baldelli R, Arvat E, Ghigo F, Casanueva FF \& Dieguez C 2000 Ghrelin elicits a marked stimulatory effect on GH secretion in freely-moving rats. European Journal of Endocrinology 143 R7-R9.

Shimizu Y, Nagaya N, Teranishi Y, Imazu M, Yamamoto M, Shokawa T, Kangawa K, Kohno N \& Yoshimuzi M 2003 Ghrelin improves endothelial dysfunction through growth-hormone-independent mechanisms in rats. Biochemical and Biophysical Research Communications 310 830-835.

Tamura T, Irahara M, Tezuka M, Kiyokawa M \& Aono T 1999 Orexins, orexigenic hypothalamic neuropeptides, suppress the pulsatile secretion of luteinizing hormone in ovariectomized female rats. Biochemical and Biophysical Research Communications 264 759-762.
Tayaka K, Ariyasu H, Hanamoyto N, Iwakura H, Yoshimoto A, Harada M, Mori K, Komatsu Y, Usui T, Shimatsu A, et al. 2001 Ghrelin strongly stimulates growth hormone release in humans. Journal of Clinical Endocrinology and Metabolism 86 1464-1469.

Tena-Sempere $\mathbf{M}$ \& Barreiro $\mathbf{M L} 2002$ Leptin in male reproduction: the testis paradigm. Molecular and Cellular Endocrinology 188 9-13.

Tena-Sempere M, Barreiro ML, González LC, Gaytán F, Zhang FP, Caminos JE, Pinilla L, Casanueva FF, Diéguez C \& Aguilar E 2002 Novel expression and functional role of ghrelin in rat testis. Endocrinology 143 717-725.

Tena-Sempere $M$, Aguilar $E$, Fernández-Fernández R, FernándezFernández R \& Pinilla L 2004 Ghrelin inhibits prolactin secretion in prepubertal rats. Neuroendocrinology 79 133-141.

Torsello A, Scibona B, Leo G, Bresciani E, Avallone R, Bulgarelli I, Luoni M, Zoll M, Rindi G, Cocchi D, et al. 2003 Ontogeny and tissue-specific regulation of ghrelin mRNA expression suggest that ghrelin is primarily involved in the control of extraendocrine functions in the rat. Neuroendocrinology 77 91-99.

Unniappan S \& Peter RE 2004 In vitro and in vivo effects of ghrelin on luteinizing hormone and growth hormone release in goldfish. American Journal of Physiololgy. Regulatory, Integrative and Comparative Physiology 286 R1093-R1101.

Vulliémoz NR, Xiao E, Xia-Zhang L, Germond M, Rivier J \& Ferin M 2004 Decrease in luteinizing hormone pulse frequency during a fivehour peripheral ghrelin infusion in the ovariectomized rhesus monkey. Journal of Clinical Endocrinology and Metabolism 89 5718-5723.

Wren AM, Small CJ, Ward HL, Murphy KG, Dakin CL, Taheri S, Kennedy AR, Roberts GH, Morgan DGA, Ghatei MA, et al. 2000 The novel hypothalamic peptide ghrelin stimulates food intake and growth hormone secretion. Endocrinology $1414325-4328$.

Received 25 September 2006

First decision 2 November 2006

Revised manuscript received 21 February 2007

Accepted 6 March 2007 